\title{
Molecular Docking Studies to Identify Promising Natural Inhibitors Targeting SARS-CoV-2 Nsp10- Nsp16 Protein Complex
}

\author{
SARS-CoV-2 Nsp10- Nsp16 Protein Kompleksini Hedefleyen Umut Veren \\ Doğal İnhibitörleri Belirlemek için Moleküler Docking Çalışmaları
}

\author{
(D) Anuradha BHARDWAJ ${ }^{1}$, (D) Swati SHARMA ${ }^{2 *}$, (D) Sandeep Kumar SINGH 3 \\ 1 Gautam Buddha University, Greater Noida, Uttar Pradesh, India \\ 2Department of Pharmacology, All India Institute of Medical Sciences, New Delhi, India \\ 3 Indian Scientific Education and Technology (ISET) Foundation, Lucknow, India
}

\section{ABSTRACT}

Objectives: Unavailability of potential drugs/vaccines in the outbreak of the pandemic severe acute respiratory syndrome-coronavirus-2 (SARSCoV-2) have devastated the human population globally. Several druggable targets have been analyzed against different viral proteins such as the spike protein. The study aims to explore the potential of natural compounds as an effective drug against a novel nsp10-nsp16 complex of SARSCoV-2 using in silico approaches.

Materials and Methods: In silico screening (Docking analysis) was performed for 10 shortlisted natural compounds viz. allicin, ajoene, carvacrol, coumarin, curcumin, menthol, eugenol, theaflavin, ursolic acid, and catechin against a novel target of SARS-CoV-2, that has been anticipated to provide valuable lead molecules and potentially druggable compounds for the treatment of SARS-CoV-2.

Results: Theaflavin and catechin, the natural components of black tea and green tea, out of 10 shortlisted compounds have shown excellent performance in our docking studies with the minimum binding energy of $-11.8 \mathrm{kcal} / \mathrm{mol}$ and $-9.2 \mathrm{kcal} / \mathrm{mol}$ respectively, against a novel nsp10-nsp16 complex of SARS-CoV-2 that indicates their potential for inhibitory molecular interactions against the virus to assist rapid drug designing from natural products.

Conclusion: Either consumption of black tea and green tea or repurposing them as drug candidates may help individuals to fight against SARSCoV-2, subject to their in vivo and in vitro further experimental validations.

Key words: SARS-CoV-2, nsp10-nsp16 protein complex, natural compounds, molecular docking, corona, antiviral natural compounds, drug design

ÖZ

Amaç: Şiddetli akut solunum sendromu-koronavirüs-2 (SARS-CoV-2) pandemi salgınında, potansiyel ilaçların/aşıların bulunamaması, küresel olarak insan popülasyonunu tahrip etmiștir. Spike proteini gibi farklı viral proteinler, ilaç uygulanabilecek bazı hedefler olarak analiz edilmiştir. Bu çalışma, SARS-CoV-2 nsp10-nsp-16 kompleksine karşı etkili bir ilaç olarak doğal bileşiklerin potansiyelini, in siliko yaklaşımlar kullanarak araştırmayı amaçlamaktadır.

Gereç ve Yöntemler: In siliko taramalar (Docking analizi), yeni bir SARS-CoV-2 hedefinin tedavisi için değerli öncü moleküller ve ilaç olarak uygulanabilir potansiyelde bileşikler sağlaması beklenen, aday listeye alınmış 10 doğal bileşik olan allisin, ajoen, karvakrol, kumarin, kurkumin, mentol, öjenol, teaflavin, ursolik asit, kateşin üzerinde gerçekleștirilmiştir.

Bulgular: Aday listede yer alan 10 bileșikten, siyah çay ve yeșil çayın doğal bileșenleri olan, theaflavin ve kateșin, yeni bir SARS-CoV-2 nsp10nsp16 kompleksine karşı sırasıyla $-11,8 \mathrm{kcal} / \mathrm{mol}$ ve $-9,2 \mathrm{kcal} / \mathrm{mol}$ minimum bağlanma enerjisi ile docking çalışmalarımızda mükemmel performans göstermiştir; bu da doğal ürünlerin, virüse karşı inhibitör moleküler etkileşimli, hızlı ilaç tasarımına yardımcı, potansiyellerini vurgulamaktadır.

Sonuç: Siyah çay ve yeșil çayın tüketilmesi veya ilaç adayları olarak yeniden kullanılması, in vivo ve in vitro ileri deneysel validasyonlarının tamamlanmasıyla, SARS-CoV-2'ye karşı savașta yardımcı olabilir.

Anahtar kelimeler: SARS-CoV-2, nsp10-nsp16 protein kompleksi, doğal bileşikler, moleküler docking, korona, doğal anti-viral bileşikler, ilaç tasarımı

*Correspondence: mail_swati84@yahoo.co.in, Phone: +9873730885, ORCID-ID: orcid.org/0000-0002-8732-335X

Received: 26.04.2021, Accepted: 30.06.2021

๑Turk J Pharm Sci, Published by Galenos Publishing House. 


\section{INTRODUCTION}

A new coronavirus, officially named severe acute respiratory syndrome-coronavirus (SARS-CoV-2) by the International Committee on Taxonomy of Viruses outburst an alarming outbreak of a pneumonia-like illness, originating without a serious known origin from the seafood market of Wuhan City, Hubei, China in December 2019.' Sooner, its human-tohuman transmission was also observed with a toll of 1,781,776 total deaths across the globe as per record till dated 28 December 2020. The World Health Organization realized the censoriousness of this infection and declared it as a global public health emergency on 30 January 2020 and a pandemic on 11 March 2020. ${ }^{2}$ The lack of effective vaccines \& approved drugs and the rapidly spreading of the virus through respiratory droplets or contact with infected droplets along with its long incubation period has worsened the situation with a toll of $81,680,270$ total confirmed cases reported across the globe by December 28, 2020 compared with the previously known CoV epidemics like SARS-CoV in 2003 and middle east respiratory syndrome-CoV in 2012 with the total number of cases reported to be 8,439 and 2,519 respectively. ${ }^{3}$

SARS-CoV-2 mark onset with clinical symptoms like pneumonia, fever, dry cough, headache, and dyspnea leading to respiratory failure in case of severe infection and weaker immunity and even death in many cases. The members of the pathogenic corona family mainly have five protein regions namely replicase complex (ORF1ab), spike (S), envelope (E), membrane (M), and nucleocapsid $(\mathrm{N})$ proteins that control the virus structure assembly and viral replications. The ORF1ab gene encodes the non-structural proteins (nsp) of the viral RNA synthesis complex through proteolytic processing. Sharing genetically similar to SARS-CoV, ${ }^{4}$ the virus SARS-CoV-2 is a spherically enveloped pathogen bearing glycoprotein projections with single-stranded RNA (ssRNA) (+ve sense RNA) associated with a nucleoprotein within a capsid.

Recently, the research on various aspects of identifying novel antiviral compounds against the SARS-CoV-2 gained significant momentum. A wide spectrum of vaccines has now been proposed and approved for emergency use across the globe. Various pharmacological methods are currently under study, primarily focusing on repurposing drugs. Despite extensive experimental and computational studies, there is no proven discovery of SARS-CoV-2 drug treatment. However, many effective and potential drug targets are already being identified against SARS-CoV-2.

More than 20 proteins constitute the viral structure out of which 3 -chymotrypsin-like protease ( $3 \mathrm{CL}^{\mathrm{pro}} / \mathrm{M}^{\mathrm{pro}}$ ) plays an important role in viral replication and is a promising drug target of SARSCoV-2. ${ }^{4} \mathrm{~A}$ recent study suggests that a complex of two critical non-structural proteins nsp10-nsp16 is also critical for virus survival and reproduction. This complex encodes 2'-O-MTase that helps the virus hide from the innate immune system of the host by modifying its genetic material in such a way that it resembles the host (human) cell RNA. ${ }^{5}$ This gives the virus enough time to exponentially multiply in the human body. Thus, developing a drug targeting the nsp10-nsp16 complex of SARSCoV-2 will empower the infected immune system to identify the pathogen and destroy it.

For ages, traditional plant products having various polyphenolic contents are popularly known for their medicinal properties. Effective treatments using plant-derived drugs have proved their immense potential by providing relief in many pathogenic diseases, including viral diseases. Realizing the potential of these natural drugs, need was felt to explore their interaction profiles with SARS-CoV-2 to identify novel drug compounds to inhibit this virus with least/no side effects. Several natural compounds such as allicin, ajoene, carvacrol, catechin, coumarin, curcumin, quercetin, baicalein, narasin, menthol, eugenol, theaflavin and ursolic acid, myricetin, raoulic acid, chebulagic acid, etc. are effective against human viral infections. ${ }^{6}$ Therefore, to defeat corona, there is need realized to scan the active compounds from the plant extracts using computational approaches to accelerate the process of drug discovery.

SARS-CoV-2 has significant similarities with the influenza virus in terms of modes of transmission, clinical signs and symptoms, and immune responses. The potential of 10 plant-derived compounds viz. allicin, ajoene, carvacrol, coumarin, curcumin, menthol, eugenol, theaflavin, ursolic acid, and catechin has been confirmed active against human influenza ${ }^{7}$ have been chosen for this study. Thus, we firstly computationally screened these 10 natural compounds against the SARS-CoV-2 nsp10-nsp16 protein complex to identify their potential to inhibit SARS-CoV-2. Later, we conducted molecular docking studies to understand their molecular interactions and mechanism of action against the pathogen growth in the human host. Our study comprises sequence and structural analysis of the potential target protein nsp10-nsp16 complex of SARS-CoV-2. Docking studies were conducted using the latest version of the AutoDock-Vina tool. ${ }^{8}$ Our approach of computationally screening these plant-derived compounds (secondary metabolites) against the target of SARS-CoV-2 infection can provide valuable lead molecules and potentially druggable compounds for treating SARS-CoV-2.

\section{MATERIALS AND METHODS}

\section{Hardware and software}

This study was conducted on a Workstation (Dell) having a 6 GB RAM \& 1 TB hard storage capacity, installed with AutoDock Vina 1.1.2 version. We also accessed web-based databases and tools online in this work.

\section{Data collection}

The viral nsp10-nsp16 complex was chosen as the potential drug target. The protein sequence and structure of the target protein complex was extracted from the protein data bank (PDB) (www.rcsb.org) with accession ID 6W4H.

\section{Sequence analyses}

Physicochemical parameters of the SARS-CoV-2 nsp10-nsp16 protein complex (both chains separately) including isoelectric point, instability index, hydropathicity, the atomic composition was computed using the ProtParam tool of ExPASy. ${ }^{9}$ 


\section{Structural analyses}

From the data repository of proteins, PDB (https://rcsb.org/), 1.80 angstrom resolution crystal Structure of nsp10-nsp16 complex from SARS-CoV-2 with PDB ID: 6W4H was retrieved in the.pdb format. Yet Another Scientific Artificial Reality Application (YASARA) ${ }^{10}$ energy minimization server was employed for initial quality assessment, structural refinement and energy minimization of the target protein structure with its reliability evaluation through ProCheck, $\left.{ }^{11}\right]$ ProSA-web, ${ }^{12}$ ProQ ${ }^{13}$ and ERRAT server. ${ }^{14}$

\section{Ligand preparation and molecular docking}

From the PubChem database chemical structures of 10 potential phytochemicals having antiviral properties namely (A) allicin, (B) ajoene, (C) carvacrol, (D) coumarin, (E) curcumin, (F) menthol, (G) eugenol, (H) theaflavin, (I) ursolic acid, (J) catechin, was fetched (Table 1). ${ }^{15}$ Both ligands and receptor molecules (nsp10-nsp16) were prepared in AutoDock Vina software, to predict our small molecule to the target receptors by performing blind docking. All analyses were performed using a standard protocol. ${ }^{16}$

A grid of 50 points each in $x, y$, and $z$ directions was chosen for the docking to accommodate any possible ligand-receptor complex in our blind docking approach. The lower the value of $\Delta G$ indicates better the binding affinities between the target and the novel ligand molecule.

\section{Visualization}

The graphical user interface of the PyMOL tool was used to visualize structure files and the protein-ligand interactions were prepared in LigPlot. ${ }^{17}$

No statistical analysis was performed in this study.

\section{RESULTS}

\section{SARS-CoV-2 viral genome structure}

SARS-CoV-2 is a spherical, non-segmented enveloped virus with the largest known ssRNA as the genetic material of approximately $30 \mathrm{~kb}$ in length. SARS-CoV-2 Wuhan-Hu-1 isolate with 29,903 bp long RNA was the first full viral genome sequenced (GenBank ID: MN908947.3). The study of the genome sequence indicates that the $5^{\prime}$ end is capped and the $3^{\prime}$ end is polyadenylated comprising 2 non-coding untranslated regions, structural proteins (S, E, M, and N) (Figure 1). and accessory proteins (ORF1ab) replicase genes. Numerous reading frames encode several proteins. The largest ORF is ORF1a/b, located at the $5^{\prime}$ end of the genome, and it encodes 15 nsps (nsp1-10 and nsp12-nsp16). ${ }^{18}$

\section{Target protein sequence and structural analyses}

We analysed the physicochemical parameters of the SARSCoV-2 nsp10-nsp16 protein complex, both the chains separately. The instability index of a protein provides an estimate of the stability of the protein in the test tube. Based on the weight value of different dipeptides, a protein with an instability index smaller than 40 is considered stable. Our results revealed the good stability of this protein complex with an instability index of 25.95 and 34.04 for the two chains of the nsp10-nsp16 complex respectively (Table 2 ).

\section{Structure evaluation of natural ligand molecules}

The chemical structures of our 10 potential antiviral phytochemicals- (A) allicin, (B) ajoene, (C) carvacrol, (D) coumarin, (E) curcumin, (F) menthol, (G) eugenol, (H) theaflavin, (I) ursolic acid, (J) catechin, were obtained from the PubChem repository (Figure 2).

Structure evaluation and validation of nsp10-nsp16 complex receptor

The complex nsp10-nsp16 protein of coronavirus is a protein with two chains: nsp10 is of 142 amino acids long sequence and the other nsp16 is 301 amino acid residues. The experimentally determined structure (X-Ray Diffraction) of our target complex with 1.80 Angstrom resolution crystal structure of nsp16-nsp10 complex was obtained from the (PDB ID: 6W4H) (Figure 3). ${ }^{19}$

To validate the structure, the energy minimization and structural refinement of the above structure of the target was done using YASARA Energy Minimization Server. We could optimize the energy of the structure from $6632175.4 \mathrm{~kJ} / \mathrm{mol}$ (score, -1.44)

Table 1. Antiviral compounds from plant-derived resources

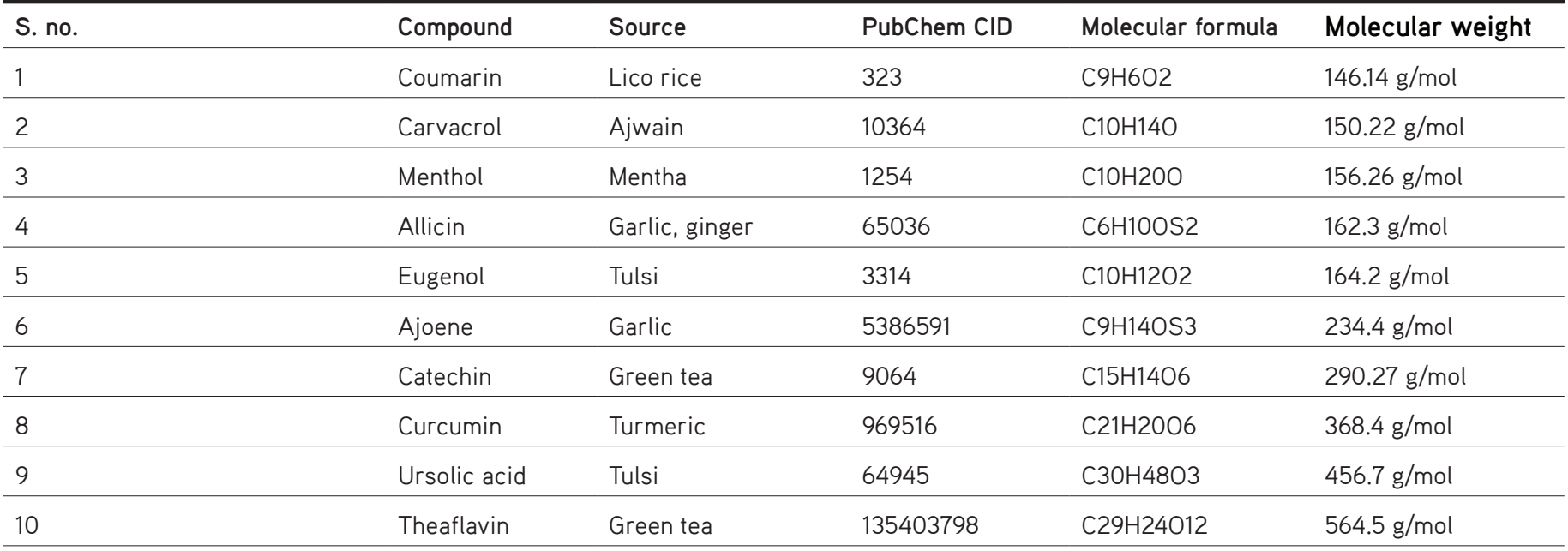


to $330675.5 \mathrm{~kJ} / \mathrm{mol}$ (score, 0.23) in the refined model. The stereochemistry of the refined model of target nsp10-nsp16 complex was then subjected to ProCheck for stereochemical analysis. The results have been shown on the Ramachandran plot, where most residues (98.8\%) were occupying the most favorable region (red), allowed zones (yellow) and the remaining $0.8 \%$ of residues were in the generously allowed region (light yellow) followed by only $0.4 \%$ residues falling in the most unfavorable zone of the disallowed region (white) (Figure 4).

We also analyzed our protein in the ProSA-web server for protein structure analysis where a good Z score of -7.18 (Figure $5 a)$ was obtained. The high accuracy of our structure was supported by Levitt-Gerstein's (LG) score of 6.388 and Maxus 0.370 extracted in the Protein Quality Predictor (ProQ) (Figure $5 b$ ) tool. A ProQ LG score $>2.5$ suggests the good quality of the model structure. The quality factor for A chain so obtained 98.966 and quality factor for B chain was 96.5035 (Figure 6a, b) in the ERRAT plot (which is used to evaluate and validate the crystal structure of a protein in which the error values are plotted as a function of the sliding 9-residue window location), further ensure the quality and reliability of structure as the higher quality score indicates higher quality. The regions of the structure that may be rejected at the $95 \%$ confidence level

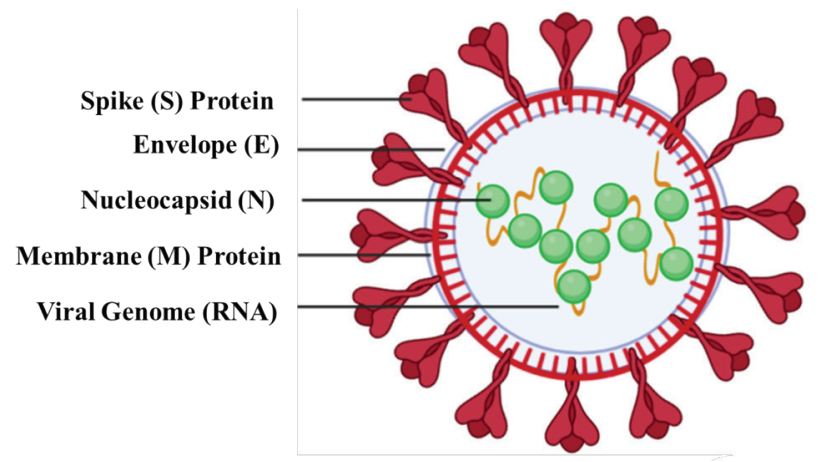

Figure 1. SARS-CoV-2 viral genome structure

SARS-CoV-2: Severe acute respiratory syndrome-coronavirus-2 are represented as yellow bars. The outcomes of our work recommend the stability, quality and reliability of the target protein structure.

\section{Docking analysis of SARS-CoV-2 nsp10-nsp16 protein complex with plant-derived ligands}

Earlier studies on the nsp10-nsp16 complex of coronavirus suggest that this complex is crucial for replicating the virus in hosts. ${ }^{20}$ In this study, we selected the most recent structure of the nsp10-nsp16 complex of SARS-CoV-2 from PDB and performed the docking analysis of this target with 10 selected compounds obtained from the natural origin showing inhibitory effects for viral infections. Our study using in silico docking tools also confirmed the findings inhibitory properties of 10 selected natural compounds against target protein (nsp10-nsp16) in multiple conformations with the given range of binding energies (Table 3). The docking interactions profile of 10 selected natural antiviral compounds with nsp10-nsp16 protein complex of SARS-CoV-2 can be easily understood by the interaction of their ligands with the active site residues of receptors by forming hydrogen bonds drawn by LigPlot (Figure 7).

Our study shows that 7 out of 10 selected anti-viral natural compounds demonstrated remarkable results in our docking analysis with binding energies less than the upper threshold (-6kcal/mol), of generally accepted cut-off in ligand-binding/ docking studies. ${ }^{21}$ Our research reveals that theaflavin and catechin are the most promising candidates among all selected natural compounds we screened against the nsp10-nsp16 protein complex. The ligand theaflavin, a polyphenolic compound, docks with the target protein complex with the least binding energy of $-11.8 \mathrm{kcal} / \mathrm{mol}$. The theaflavin ligand interacts with the target molecule by forming a hydrogen bond with Ala285, Asp289, Gly283, Arg4, and Lys5 amino acid. The polyphenolic compound catechin ligand was found to interact with the target nsp10-nsp16 complex with binding energy of $-9.2 \mathrm{kcal} / \mathrm{mol}$. The major amino acid residues involved in the hydrogen bonds between the ligand and receptor are Arg4, Glu288, Lys5 and Gln127. Both these significant polyphenolic natural compounds

\section{Table 2. Physicochemical parameters of SARS-CoV-2 nsp10-nsp16 complex}

\begin{tabular}{llll} 
S. no. & Parameters & SARS-CoV-2 nsp16 & SARS-CoV-2 nsp10 \\
\hline 1 & Molecular weight & 33595.58 & 15062.19 \\
\hline 2 & Number of amino acids & 301 & 142 \\
\hline 3 & Theoretical pl & 7.59 & 6.23 \\
\hline 4 & Instability index (II) & 25.95 & 34.04 \\
\hline 5 & $\begin{array}{l}\text { Number of negatively charged residues (Asp + } \\
\text { Glu) }\end{array}$ & 26 & 11 \\
\hline 6 & Number of positively charged residues (Arg + Lys) & 27 & 10 \\
\hline 7 & Aliphatic index & 90.07 & 61.2 \\
\hline 8 & Grand average of gydropathicity & -0.093 & -0.084 \\
\hline 9 & Atomic composition & C 1503, H 2347, N 397, O 442, S 17 & C 646, H 1007, N 177, O 204, S 17 \\
\hline
\end{tabular}

SARS-CoV-2: Severe acute respiratory syndrome-coronavirus-2 


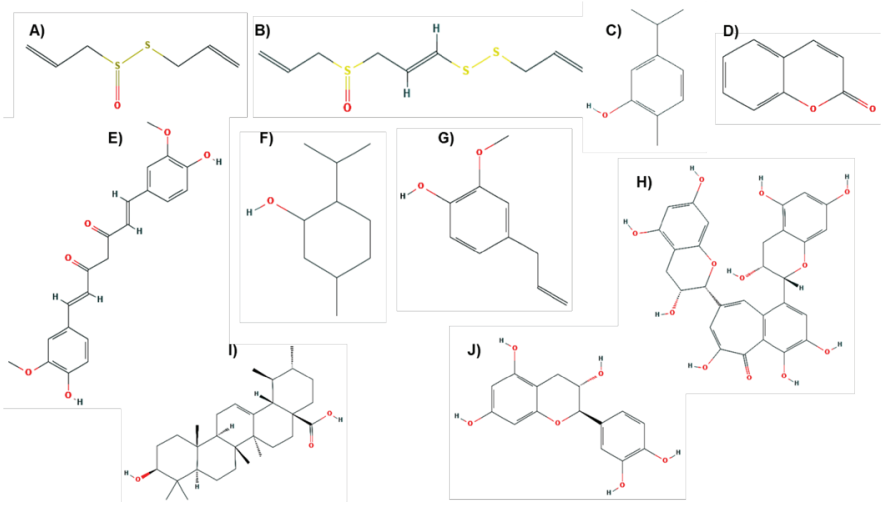

Figure 2. Chemical structures of 10 selected natural compounds with antiviral properties (A) allicin, (B) ajoene, (C) carvacrol, (D) coumarin, (E) curcumin, (F) menthol, $(G)$ eugenol, $(H)$ theaflavin, (I) ursolic acid, $(\mathrm{J})$ catechin

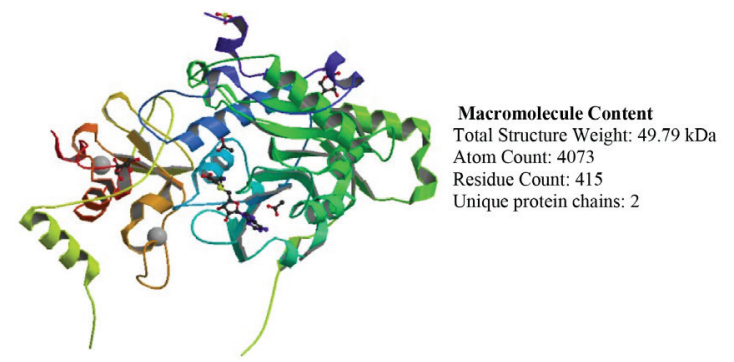

Figure 3. Target protein structure (3-D) of nsp10-nsp16 complex of SARSCOV-2

SARS-CoV-2: Severe acute respiratory syndrome-coronavirus-2

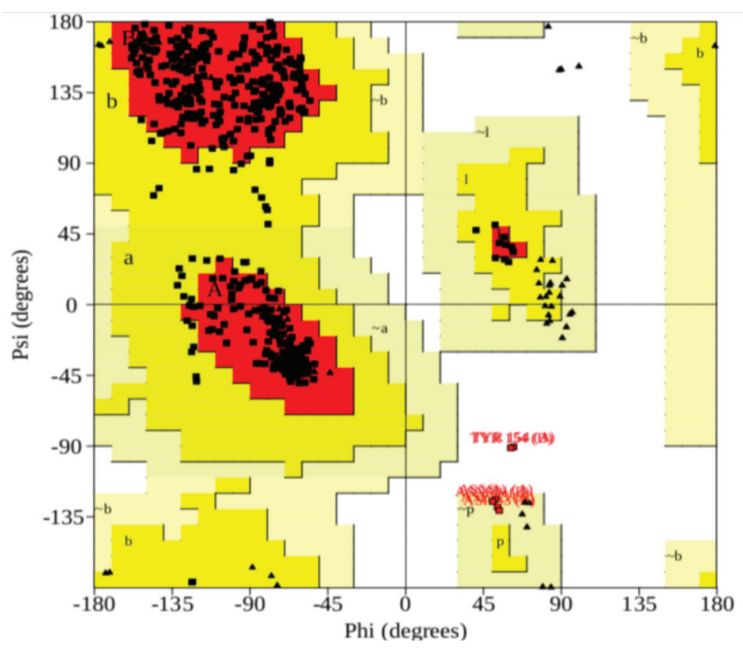

Figure 4. Ramachandran plot of target protein structure (the red, dark yellow, and light-yellow and white regions represent the most favoured, allowed, and generously allowed and disallowed regions respectively)

with anti-viral properties are present in green tea (catechin) and black tea (theaflavin) in a high amount. ${ }^{6}$

Our docking studies further revealed that ursolic acid, an active component of $O$. sanctum (tulsi) secures the third-lowest binding energy of $-8.5 \mathrm{kcal} / \mathrm{mol}$. It interacts with the receptor molecule by forming five hydrogen bonds with Glu288, Asp289, Lys137, Arg131, Thr199. Ursolic acid is used in Ayurveda for treating many diseases including swine flu, H1N1 flu, etc. and
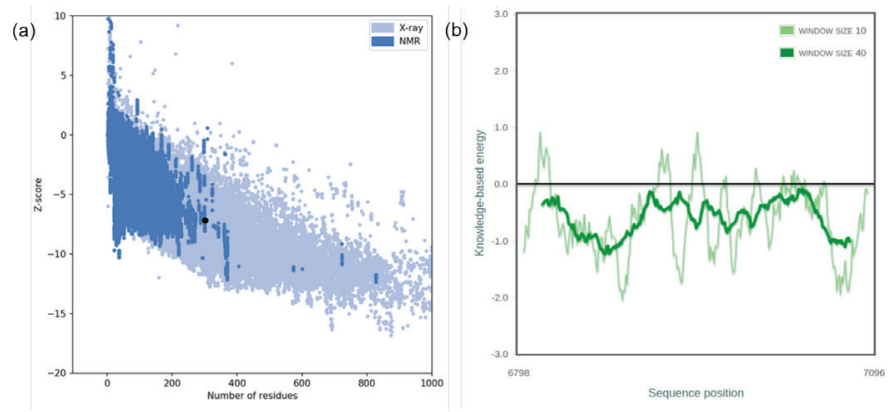

Figure 5. (a) ProSA-web Z-scores of target protein [all protein chains in protein data bank determined by X-ray crystallography (light blue) and nuclear magnetic resonance spectroscopy (dark blue) with respect to their length]. The black dot in the dark blue region represents the Z-score of our target; (b) energy plot for the nsp10-nsp16 complex of SARS-CoV-2

SARS-CoV-2: Severe acute respiratory syndrome-coronavirus-2

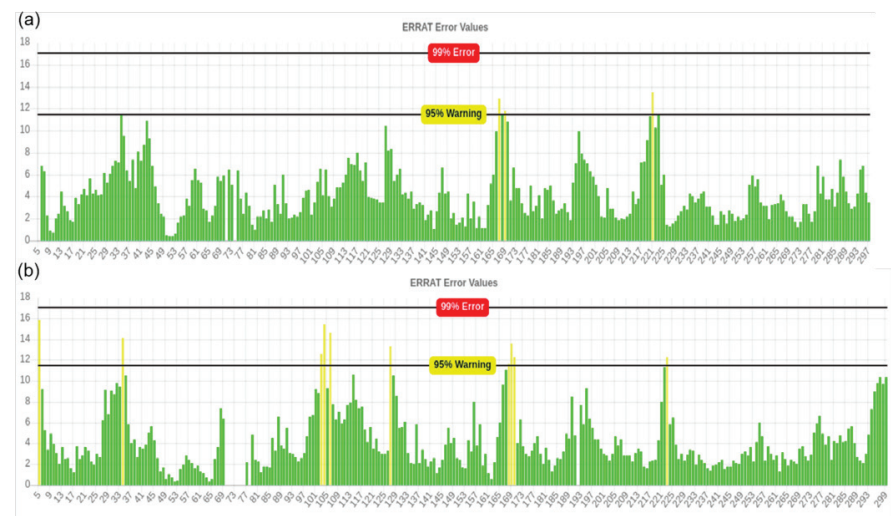

Figure 6. (a) ERRAT plot of nsp10 receptor protein chain, (b) ERRAT plot of nsp16 receptor protein chain

has tremendous antimicrobial properties. ${ }^{22}$

Curcumin is a strong antioxidant with anti-viral properties, ${ }^{23}$ and was found to have a binding energy of $-6.1 \mathrm{kcal} / \mathrm{mol}$ in our docking studies. Amino acids Lys137, Arg4, and Lys5 were involved in the hydrogen bond formation of curcumin with the target protein. Further, the interaction binding energy of menthol and nsp10-nsp16 complex was found to be $-6 \mathrm{kcal} / \mathrm{mol}$ with only one hydrogen bond with Lys 5 amino acid residues. Menthol, the principal component of the oil of M. piperita is known for its antimicrobial and antiviral activities. Its virucidal potential against certain viruses like herpes, influenza is already proved in vitro. ${ }^{22}$ Carvacrol is a component of essential oils obtained from Trachyspermum ammi commonly known as 'ajwain and is commonly used to treat cold, cough, influenza, and asthma. With binding energy of $-6.5 \mathrm{kcal} / \mathrm{mol}$, carvacrol shows promising interaction with our target via amino acid Arg4. Coumarin is a colorless natural compound with a unique flavor and fragrance. It is majorly found in "Cassia cinnamon." Coumarin is found to interact with the nsp10-nsp16 target complex with the amino acids Arg 4 and Lys5 having binding energy of $-6.1 \mathrm{kcal} / \mathrm{mol}$.

\section{DISCUSSION}

Medicinal plants have been widely used to treat many diseases ruled by viruses as pathogens. We evaluated 10 common 
Table 3. Docking results revealing polar contact information and binding energy of different ligands with nsp10-nsp16 protein target of SARS-CoV-2

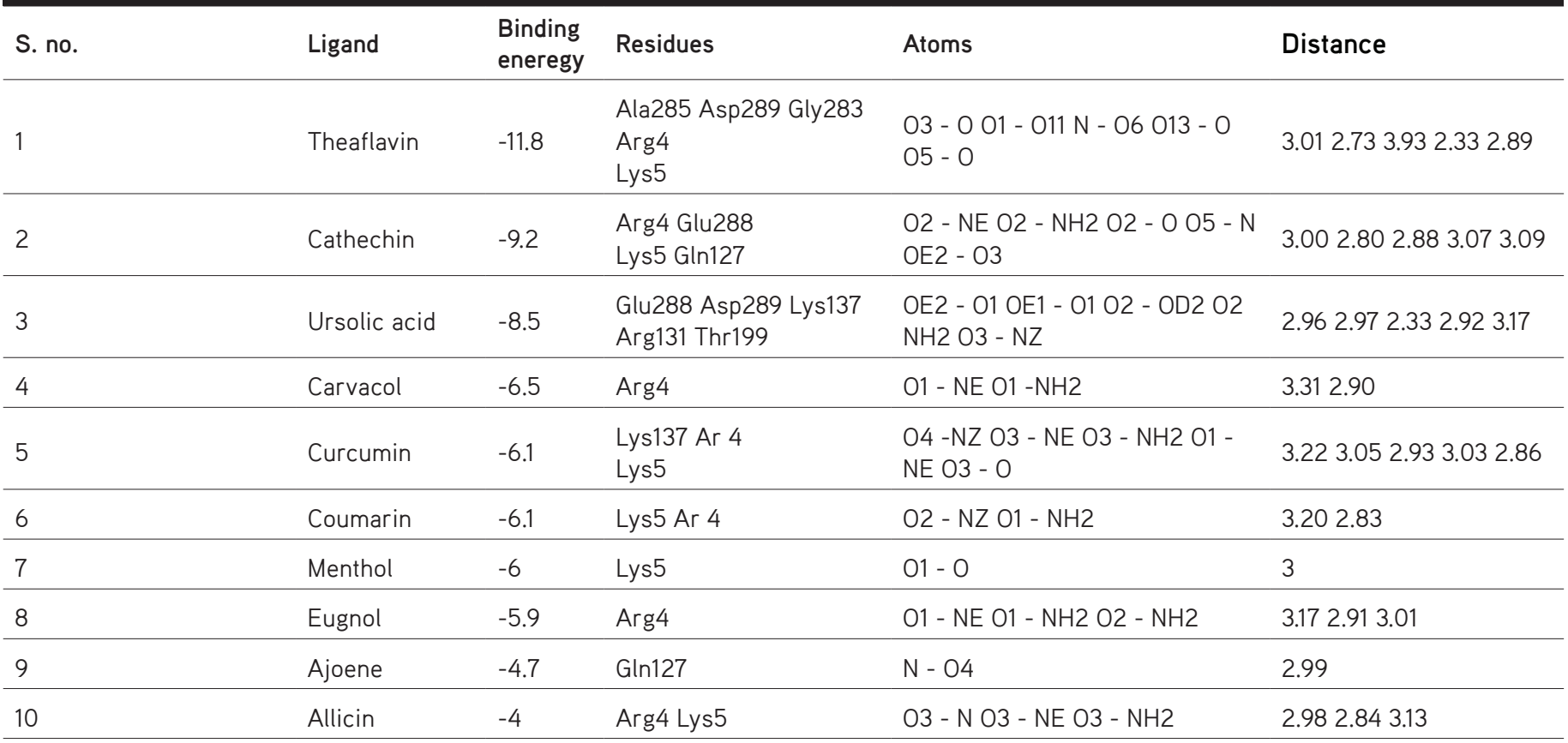

SARS-CoV-2: Severe acute respiratory syndrome-coronavirus-2

antiviral natural compounds namely allicin, ajoene, carvacrol, catechin, coumarin, curcumin, menthol, eugenol, theaflavin, and ursolic acid, out of which 7 natural compounds (Table 3) demonstrated significant results in computational analysis with binding energies less than the upper threshold $(-6 \mathrm{kcal} /$ $\mathrm{mol}$ ), which is a generally accepted cut-off in ligand-binding /docking studies. ${ }^{21}$ The binding affinity for the SARS-CoV-2 nsp10-nsp16 complex was observed lowest in the case of Theaflavin $(-11.8 \mathrm{kcal} / \mathrm{mol})$ to highest $(-4 \mathrm{kcal} / \mathrm{mol})$ for allicin. The seven natural compounds that fall in the acceptable range of binding energy are theaflavin (-11.8), catechin (-9.2), ursolic acid (-8.5), carvacrol (-6.5), curcumin (-6.1), coumarin (-6.1), and menthol (-6). Our molecular docking studies confirmed that the compounds present in tea (catechin in green tea and theaflavin in black tea) can inhibit infections from SARS-CoV-2.

Tea is one of the most commonly consumed beverages across the world and its health-promoting attributes are already validated by scientific interventions decades ago. These health benefits of tea are governed by the presence of polyphenols (flavonoids) and phytochemicals in them. Tea is prepared from the Camellia sinensis plant by harvesting and transforming the leaves into green tea or black tea by altering the flavonoid content in them.

Green tea is rich in catechin polyphenolic compounds. Catechin is already known for its health benefits including its antitumor, antioxidative, and antimicrobial activities. ${ }^{24}$ The major components of catechin are epicatechin, epicatechin gallate, epigallocatechin and epigallocatechin gallate (EGCG). ECCG is considered the main active constituent of green tea. GTCs have shown significant inhibitory activities against various viruses, such as human viruses, ${ }^{25}$ arboviruses, such as Zika virus, etc. ${ }^{26}$
In our study, we found significant binding energy of $-9.2 \mathrm{kcal} /$ mol between this compound with our target molecule through its amino acids Arg4, Glu288, Lys5, and Gln12.

Oxidation and dimerization of the green tea catechins form an orange-red pigment called theaflavin (black tea), a flavanol, which is a mixture of theaflavin (TF1), theaflavin-3gallate (TF2A), theaflavin-3'-gallate (TF2B) and theaflavin3,3'-digallate (TF3). These derivatives have exhibited potent inhibitory effects on the influenza virus in vitro. ${ }^{27}$ Theaflavins have been shown in our research to interact significantly with the receptors nsp10-nsp16 complex with amino acid residues Ala285, Asp289, Gly283, Arg4, and Lys5 with the highest binding energy of $-11.8 \mathrm{kcal} / \mathrm{mol}$. Its broad-spectrum biological properties include anti-tumor, anti-viral, anti-inflammatory, anti-oxidative, and anti-bacterial properties. ${ }^{28,29}$

Our body fight infections through its innate immunity to diminish disease progression. The impairment of our immune system results in disrupted signaling pathways upregulating the proinflammatory cytokines like interleukin-6, which may result in tissue injury and apoptosis. Theaflavin serves a dual purpose in fighting infection. Besides its function to act against the viral target protein, theaflavin also acts as a nutritional modulator and enhancer of human innate immunity response.

Hence, our in silico analysis advocates the usage of natural anti-viral compounds against SARS-CoV-2 to uncover their inhibitory potential to provide the first line of protection against this deadly virus. Our study also offers potential candidates (theaflavin \& catechin) for repurposing them as successful therapeutic drugs in time, after comprehensive studies provided in vitro and in vivo validation studies are taken up. 


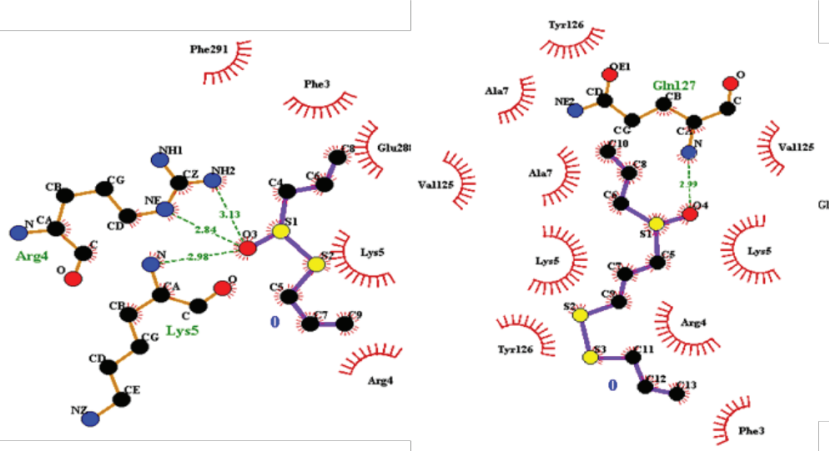

Allicin

Ajoene

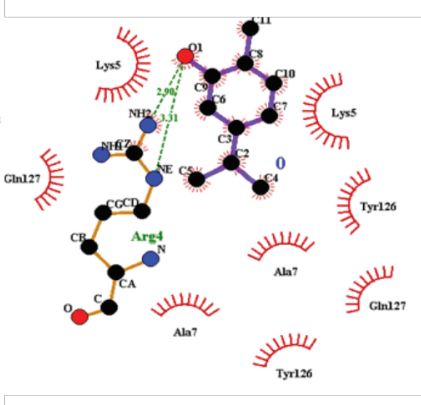

青 ${ }^{\mathrm{Ty}}$

Gill

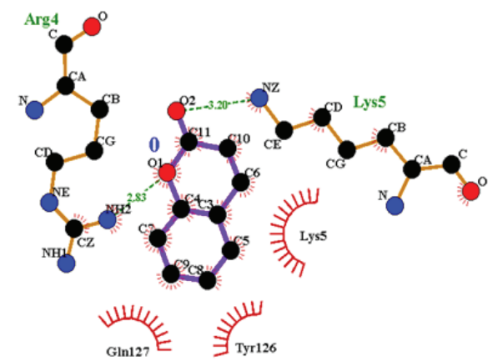

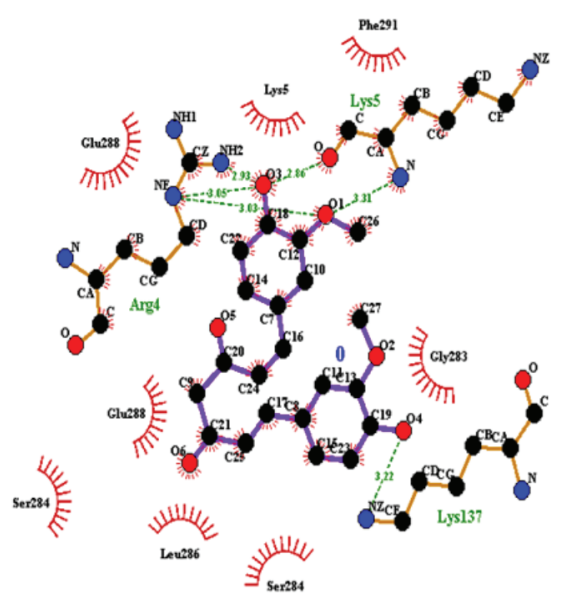

Curcumin

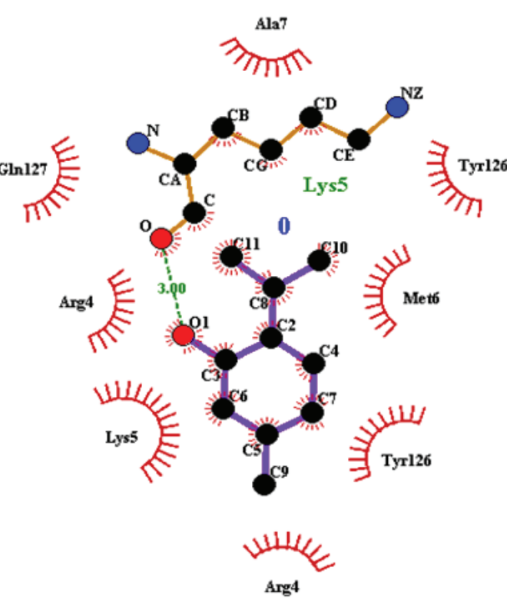

Menthol

Coumarin

Carvacrol

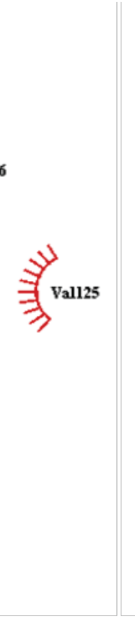

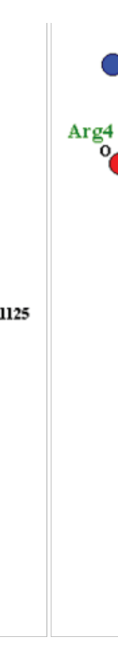
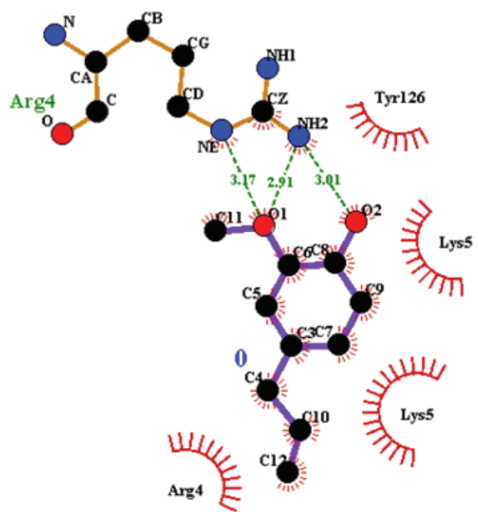

Glu28

Eugenol

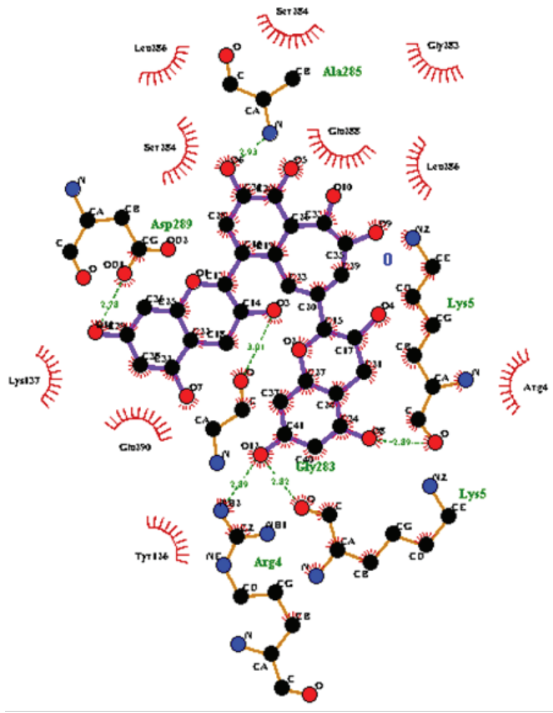

Theaflavin

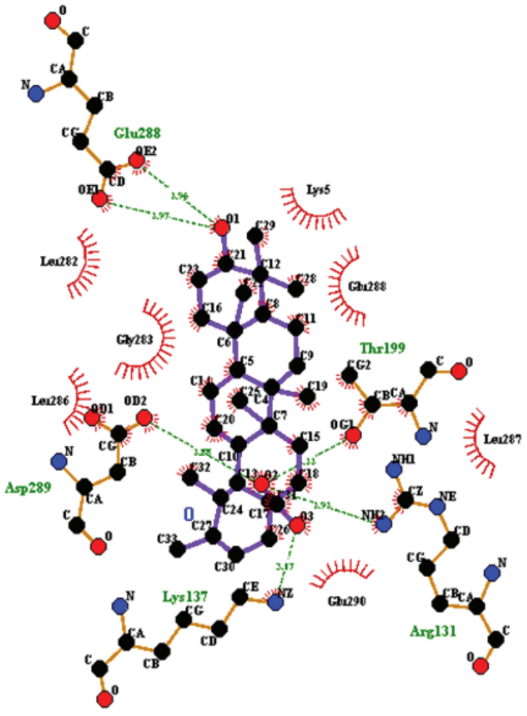

Ursolic Acid

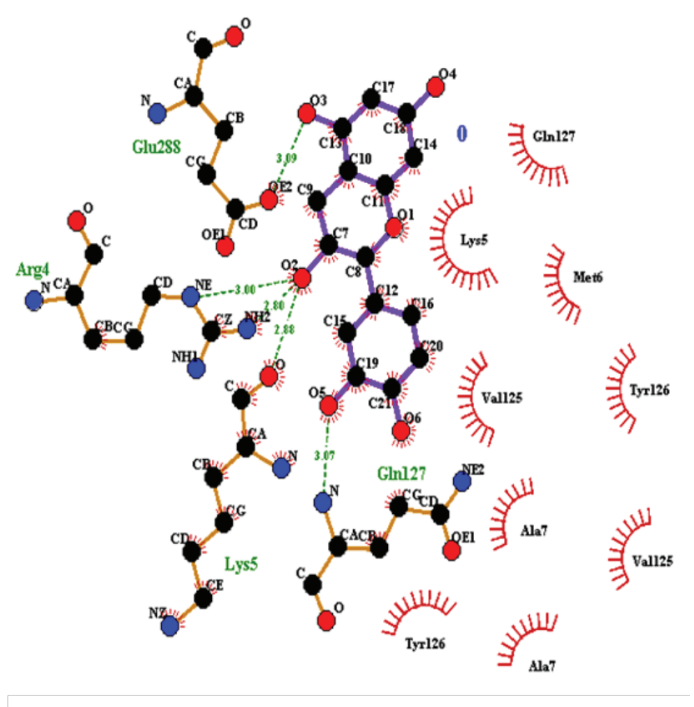

Catechin

Figure 7. Interaction profile of 10 natural antiviral compounds with nsp10-16 protein complex of SARS-CoV-2 showing the interaction of ligands with the active site residues of receptors by forming hydrogen bonds drawn by LigPlot. In the above illuastration, Ligands are colored in purple, hydrogen bonds are represented as green dash lines, and hydrophobic contacts are represented as red arcs

SARS-CoV-2: Severe acute respiratory syndrome-coronavirus-2

\section{CONCLUSION}

The recent outbreak of the pandemic SARS-CoV-2 has devastated the human population due to the unavailability of potential drugs/vaccines to inhibit the virus. This serious issue has raised immediate need to promising drug candidates to combat this epidemic. It is quite evident to use plant-derived drugs against many viral infections. Many herbal molecules have significantly reduced the viral growth majorly targeting 
$3 \mathrm{CL}^{\text {pro }}, \mathrm{PL}$ pro, $\mathrm{S}$, and angiotensin-converting enzyme 2 of SARSCoV.We have performedi in silico docking methods against a novel target of the SARS-CoV-2, nsp10-nsp16 complex to identify their inhibitory molecular interaction against the virus to assist rapid drug designing from natural products. Theaflavin and catechin, the natural components of black tea and green tea have shown excellent performance in our docking studies with the minimum binding energy of $-11.8 \mathrm{kcal} / \mathrm{mol}$ and $-9.2 \mathrm{kcal} /$ mol respectively. The lesser the value of the binding energy corresponds to a better binding affinity and thus it can be concluded that either consumption of black tea and green tea or repurposing them as drug candidates may help individuals fight against SARS-CoV-2, subject to their in vivo and in vitro further validatory steps.

Conflict of interest: No conflict of interest was declared by the authors. The authors are solely responsible for the content and writing of this paper.

\section{REFERENCES}

1. Zhou P, Yang XL, Wang XG, Hu B, Zhang L, Zhang W, Si HR, Zhu Y, Bei Li B, Huang CL, Chen HD, Chen J, Luo Y, Guo H, Jiang RD, Liu MQ, Chen $Y$, Shen XR, Wang X, Zheng XS, Zhao K, Chen QJ, Deng F, Liu LL, Yan B, Zhan FX, Wang YY, Xiao GF, Shi ZL. A pneumonia outbreak associated with a new coronavirus of probable bat origin. Nature. 2020;579:270273.

2. Cucinotta D, Vanelli M. WHO Declares COVID-19 a Pandemic. Acta Biomed. 2020;91:157-160

3. Yin Y, Wunderink RG. MERS, SARS and other coronaviruses as causes of pneumonia. Respirology. 2018;23:130-137.

4. Anand K, Ziebuhr J, Wadhwani P, Mesters JR, Hilgenfeld R. Coronavirus main proteinase (3CLpro) structure: basis for the design of anti-SARS drugs. Science. 2003;300:1763-1767.

5. Vithani N, Ward MD, Zimmerman MI, Novak B, Borowsky JH, Singh S, Bowman GR. SARS-CoV-2 Nsp16 activation mechanism and a cryptic pocket with pan-coronavirus antiviral potential. bioRxiv [Preprint]. 2020. doi: 10:2020.12.10.420109.

6. Yiannakopoulou ECh. Recent patents on antibacterial, antifungal and antiviral properties of tea. Recent Pat Antiinfect Drug Discov. 2012;7:60-65.

7. Sahoo M, Jena L, Rath SN, Kumar S. The identification of suitable natural inhibitor against influenza A (H1N1) neuraminidase protein by molecular docking. Genomics Inform. 2016;14:96-103.

8. Trott O, Olson AJ. AutoDock Vina: improving the speed and accuracy of docking with a new scoring function, efficient optimization, and multithreading. J Comput Chem. 2010;31:455-461.

9. Gasteiger E, Gattiker A, Hoogland C, Ivanyi I, Appel RD, Bairoch A. ExPASy: the proteomics server for in-depth protein knowledge and analysis. Nucleic Acids Res. 2003;31:3784-3788.

10. Krieger E, Joo K, Lee J, Lee J, Raman S, Thompson J, Tyka M, Baker D, Karplus K. Improving physical realism, stereochemistry, and side-chain accuracy in homology modeling: four approaches that performed well in CASP8. Proteins. 2009;(Suppl 9):114-122.
11. Laskowski RA, MacArthur MW, Moss DS, Thornton JM. PROCHECK: a program to check the stereochemical quality of protein structures. J Appl Crystallogr. 1993;26:283-291.

12. Wiederstein M, Sippl MJ. ProSA-web: interactive web service for the recognition of errors in three-dimensional structures of proteins. Nucleic Acids Res. 2007;(Web Server issue):W407-W410.

13. Wallner B, Elofsson A. Can correct protein models be identified? Protein Sci. 2003;12:1073-1086.

14. Colovos C, Yeates TO. Verification of protein structures: patterns of nonbonded atomic interactions. Protein Sci. 1993;2:1511-1519.

15. Torkamani A, Andersen KG, Steinhubl SR, Topol EJ. High-definition medicine. Cell. 2017;170:828-843.

16. Morris GM, Huey R, Lindstrom W, Sanner MF, Belew RK, Goodsell DS, Olson AJ. AutoDock4 and AutoDockTools4: Automated docking with selective receptor flexibility. J Comput Chem. 2009;30:2785-2791.

17. Wallace AC, Laskowski RA, Thornton JM. LIGPLOT: a program to generate schematic diagrams of protein-ligand interactions. Protein Eng. 1995;8:127-134.

18. Mittal A, Manjunath K, Ranjan RK, Kaushik S, Kumar S, Verma V. COVID-19 pandemic: insights into structure, function, and hACE2 receptor recognition by SARS-CoV-2. PLoS Pathog. 2020;16:e1008762.

19. Rosas-Lemus M, Minasov G, Shuvalova L, Inniss NL, Kiryukhina O, Brunzelle J, Satchell KJF. High-resolution structures of the SARSCoV-2 2'-O-methyltransferase reveal strategies for structure-based inhibitor design. Sci Signal. 2020;13:eabe1202.

20. Wang $Y$, Sun $Y$, Wu A, Xu S, Pan R, Zeng C, Jin X, Ge X, Shi Z, Ahola T, Chen $Y$, Guo D. Coronavirus nsp10/nsp16 methyltransferase can be targeted by nsp10-derived peptide in vitro and in vivo to reduce replication and pathogenesis. J Virol. 2015;89:8416-8427.

21. Mukhtar M, Arshad M, Ahmad M, Pomerantz RJ, Wigdahl B, Parveen Z. Antiviral potentials of medicinal plants. Virus Res. 2008;131:111-120.

22. Naik GH, Priyadarsini KI, Naik DB, Gangabhagirathi R, Mohan H. Studies on the aqueous extract of Terminalia chebula as a potent antioxidant and a probable radioprotector. Phytomedicine. 2004;11:530-538.

23. Praditya D, Kirchhoff L, Brüning J, Rachmawati H, Steinmann J, Steinmann E. Anti-infective properties of the golden spice curcumin. Front Microbiol. 2019;10:912.

24. Chacko SM, Thambi PT, Kuttan R, Nishigaki I. Beneficial effects of green tea: a literature review. Chin Med. 2010;5:13.

25. Ide K, Kawasaki Y, Kawakami K, Yamada H. Anti-influenza virus effects of catechins: a molecular and clinical review. Curr Med Chem. 2016;23:4773-4783.

26. Carneiro BM, Batista MN, Braga ACS, Nogueira ML, Rahal P. The green tea molecule EGCG inhibits Zika virus entry. Virology. 2016;496:215218.

27. Zu M, Yang F, Zhou W, Liu A, Du G, Zheng L. In vitro anti-influenza virus and anti-inflammatory activities of theaflavin derivatives. Antiviral Res. 2012;94:217-224.

28. Yang CS, Landau JM. Effects of tea consumption on nutrition and health. J Nutr. 2000;130:2409-2412.

29. Higdon JV, Frei B. Tea catechins and polyphenols: health effects, metabolism, and antioxidant functions. Crit Rev Food Sci Nutr. 2003;43:89-143. 